\title{
Forest vegetation in western Romania in relation to climate variables: Does community composition re- flect modelled tree species distribution?
}

\author{
S. Heinrichs, H. Walentowski, E. Bergmeier, K.H. Mellert, A. Indreica, Y. Kuzyakov, Ch. \\ Leuschner, A.M. Petritan, M. Teodosiu
}

Heinrichs S., Walentowski H., Bergmeier E., Mellert K.H., Indreica A., Kuzyakov Y., Leuschner Ch., Petritan A.M., Teodosiu M., 2016. Forest vegetation in western Romania in relation to climate variables: Does community composition reflect modelled tree species distribution? Ann. For. Res. 59(2): 219-236.

Abstract. European beech (Fagus sylvatica L.) is the prevailing tree species of mesic forests in Central Europe. Increasing summer temperatures and decreasing precipitation, as climate change scenarios predict, may, however, negatively influence beech growth and induce a shift to more thermophilous forest communities. Temperatures as expected in the future for western Central Europe are currently found in parts of western Romania. In light of this climate analogy we investigated forest vegetation as an indicator for future vegetation changes in five regions of western Romania representing a climatic gradient. We related species composition to climate variables and examined if tree and understorey species composition respond similarly to the climatic gradient. We further analysed if tree species occurrences correspond with their modelled distance to the rear niche edge. We found evidence for climatic effects on vegetation composition among regions as well as within deciduous and pine forests, respectively. This underlines that vegetation composition is a useful indicator for environmental change. Tree and understorey species compositions were closely linked showing that community-based characterization of forest stands can provide additional information on tree species suitability along environmental gradients. Both, vegetation composition and a climatic marginality index demonstrate the rear niche edge occurrence of beech in the studied sites of Romania and can predict the site suitability for different tree species. While vegetation surveys indicate Quercus petraea to be associated to moderately mesic forests, the marginality index suggested an inner niche position of sessile oak along the climatic gradient. Phytosociological relevés that differentiate between subspecies (or microspecies) of sessile oak with differing habitat requirements should be considered to complement national forest inventories and species distribution maps when modelling rear distribution edges. We conclude that climate driven forest vegetation composition in western Romania is a suitable analogon and may indicate future forest development in western Central Europe.

Keywords climate analogy, climate change, Fagus sylvatica, plant community, 
Quercus petraea, climatic marginality index, rear edge populations

Authors. Steffi Heinrichs, Helge Walentowski (helge.walentowski@hawk-hhg. de) - Faculty of Resource Management, University of Applied Sciences and Arts Hildesheim/Holzminden/Göttingen, Büsgenweg 1a, 37077 Göttingen, Germany; Erwin Bergmeier - Department of Vegetation and Phytodiversity Analysis, Georg-August University of Göttingen, Untere Karspüle 2, 37073 Göttingen, Germany; Karl Heinz Mellert - Department Forest Nutrition and Water Resources, TUM School of Life Sciences, Hans-Carl-von-CarlowitzPlatz 2, 85354 Freising, Germany; Adrian Indreica - Department of Silviculture, Transilvania University of Brasov, Șirul Beethoven 1, 500123 Brașov, Romania; Yakov Kuzyakov - Department of Soil Science of Temperate Ecosystems, Georg-August University of Göttingen, Büsgenweg 2, 37077 Göttingen, Germany; Christoph Leuschner - Department of Plant Ecology and Ecosystem Research, Georg-August University of Göttingen, Untere Karspüle 2, 37073 Göttingen, Germany; Any Mary Petrițan, Marius Teodosiu - Department of Forest Ecology, "Marin Drăcea" National Research-Development Institute in Forestry - Station Brașov, Cloșca 13, 500040 Brașov \& Station Câmpulung Moldovenesc, Calea Bucovinei 73b, 725100 Câmpulung Moldovenesc, Suceava, Romania.

Manuscript received October 3, 2016; revised November 18, 2016; accepted November 21, 2016; online first November 22, 2016.

\section{Introduction}

European beech (Fagus sylvatica L.) is the prevailing tree species of mesic forests across about two thirds of Central Europe. It is highly competitive and tolerates a wide range of abiotic (climate and soil) conditions (Ellenberg \& Leuschner 2010). Climate change is, however, expected to increasingly affect the species composition of Central European forests, in particular at lowland sites. Mesic forests mainly composed of beech may shift to more thermophilous communities characterized by oak species (Mette et al. 2013, Dolos et al. 2016). While a global analysis of climatic constraints of Fagus identified summer temperature as the main climatic factor limiting beech distribution in Europe (Fang \& Lechowicz 2006), stand-level dendroecological and ecophysiological studies have produced evidence that summer rainfall is another key factor that may restrict beech vitality and growth (Scharnweber et al. 2011, Zimmermann et al. 2015). According to the moderate RCP2.6 scenario summer temperatures in Central Europe will rise by at least $2{ }^{\circ} \mathrm{C}$ until 2070 while precipita220 tion is expected to decrease moderately (IPCC 2013). Future summer temperatures and rainfall in western Central Europe will therefore compare with values currently found in parts of western Romania, more than $1000 \mathrm{~km}$ to the South-east. This climate analogy prompted us to inspect to what extent species composition and habitat conditions of western Romanian forest sites are useful trend indicators for forest vegetation development further northwest. The zonal deciduous forest vegetation in western Romania represents a gradient from humid-mesic beech forests in the mountains at altitudes above $600 \mathrm{~m}$ to sub-humid mesic mixed beech-hornbeam and hornbeam-oak forests and to sub-humid thermophilous oak forests with Quercus cerris, Q. frainetto and Q. pubescens at lower elevations (Doniță et al. 1992, Coldea et al. 2015b). As predicted by the law of relative habitat constancy (Walter \& Breckle 1985), mesic forests occur at low elevations extrazonally on northern slopes or in valleys with increased humidity (Doniță et al. 1992). While in such extrazonal mesic forests thermophilous species from the surrounding territory may occur, they are mainly charac- 
terized by mesophilous plants, indicating the buffering mesoclimatic effect which may prevent species extinctions at the landscape scale (Lenoir et al. 2013, Maclean et al. 2015). In general, western Romanian low to mid-altitudinal mesic forests dominated by Fagus sylvatica and Quercus petraea are so-called "rear edge" populations (i.e., populations at the low-latitudinal distribution limits of a species) adapted to relatively warm and dry conditions (Hampe \& Petit 2005). It is assumed that such spatially isolated populations persisted periods of climate change in the past, and are thus particularly important for the conservation of biodiversity in the future (Rose et al. 2009, Hampe \& Jump 2011). The rear edge populations situated at or near glacial refugia are supposed to be vital long-term pools of genetic diversity (Hampe \& Petit 2005, Patricelli et al. 2013) and can be regarded as references for the estimation of species and community susceptibility to climate change (Mellert et al. 2016). Favoured presumably by increased $\mathrm{CO}_{2}$-concentration, continued nitrogen deposition and a longer vegetation period, rear edge beech populations in Albania and Macedonia showed a recent growth increase despite increasing temperature and drought (Tegel et al. 2014). Such observations underline the necessity to examine climate-analogue forest stands of western Romania more closely. The territory of western and south-western to central Romania, at the transition of the sub-Mediterranean to the Central European bioclimate, offers sequences along strong climatic and topographical gradients (e.g. altitudinal and continentality gradients between the warm-humid Iron Gates and the cold-humid Târnava Mare), extrazonal niches and azonal rocky sites.

To investigate the effects of climate on the tree and understorey species composition, we collected forest plot data in five regions of western Romania, mainly at altitudes lower than $600 \mathrm{~m}$, along these gradients associated with a change in tree species composition (Figure 1; Walentowski et al. 2015). The western lowlands (Crișana; 1. Zarand Mts. region) are mainly characterized by Pannonian-Balkan, the southwestern piedmont uplands (southern Banat; 2. Domogled region; 3. Iron Gates region) and the Olt valley (Southern Carpathians, 4. Cozia region) by Moesio-Danubian, the central Romanian piedmont uplands (Transylvania; 5. Târnava Mare region) by Dacian influences. Such striking biogeographical convergences accentuate contrasting patterns of prevalence and community composition (Walentowski \& Bergmeier 2009). We investigated three basic research questions: (i) Which species compositional shifts can be observed along the climate gradient?; (ii) Are understorey and tree species linked and do they respond similarly to climatic gradients?; (iii) Do the tree species in the survey occur in accordance with their modelled distribution and can it be predicted by climate indices such as the widely applied Ellenberg Quotient (EQ; Ellenberg 1963), the De Martonne aridity index, and the climatic marginality index, which estimates tree species' distance to the rear niche edge at a particular site (CMI; Mellert et al. 2015, 2016)?

\section{Materials and methods}

\section{Study regions and their climatic characteris- tics}

Forest vegetation was surveyed in five regions from the Iron Gate to the Transylvanian Plateau, different in climate and vegetation, and covering the planar to the colline-submontane zone (Figure 1, Table 1; Walentowski et al. 2015). The western study regions Iron Gates Natural Park (IG), Zarand Mountains (ZM) and Domogled National Park (Dom) have a warm-temperate, fully humid climate with warm summers (Cfb), a climate class characteristic of most of Central Europe (Kottek et al. 2006). The eastern study regions Târnava Mare (TM) and Cozia National Park (Coz) 
can be assigned to fully humid snow climate with warm summers (Dfb) as is characteristic for East Central Europe (Kottek et al. 2006). For each region climate data from six locations at different altitudes that are based on climate models were compiled (www.climate-data. org). To further extrapolate the climate variables to surveyed altitude, linear regressions between altitude and the climate variables annual precipitation sum $(\mathrm{Prec})$, precipitation sum from May to September $\left(\right.$ Prec $\left._{\text {May-Sep }}\right)$, mean annual temperature $(T)$, mean July temperature $\left(T_{\text {Jul }}\right)$ as the warmest month, mean January temperature $\left(T_{\mathrm{Jan}}\right)$ as the coldest month and mean temperature from May to September $\left(T_{\text {May-Sep }}\right)$ were used. In our regions, Prec increases by ca. 24-25 $\mathrm{mm}$ with $100 \mathrm{~m}$ altitude, and $T$ decreases by $0.5^{\circ} \mathrm{C}$ per $100 \mathrm{~m}$. In all five regions, $T_{\text {Jul }}$ shows the largest and $T_{\text {Jan }}$ the smallest decrease with altitude. As indicated by the lowest determination coefficient for all climate variables, in particular for $T_{\mathrm{Jan}}$, TM is characterized by a climate where winter temperatures are more extreme and less correlated with altitude (Dfb; see Supporting Information I).

To further characterize the climatic conditions of the five regions, we calculated the Ellenberg Quotient $(E Q)$ and the De Martonne aridity index for the whole year $\left(I D M_{\text {Year }}\right)$ as well as for the main growing season of trees from May to September (IDM $\left.M_{\text {May-Sep }}\right)$. The $E Q$ provides a rough characterization of the humidity of the climate and is defined as the mean temperature of the warmest month (July, $T_{\mathrm{Jul}}$ ) divided by annual precipitation (Prec): $E Q=$ $1000\left(T_{\mathrm{Jul}} /\right.$ Prec $) . E Q$ is interpreted to indicate a shift in dominance from beech to oak at values of above 30 (Ellenberg 1963). Regions IG, ZM and $\mathrm{Coz}$ are characterized by an EQ slightly $>30$, while the other two regions have values

Table 1 Characteristics of the study regions with climate variables

\begin{tabular}{|c|c|c|c|c|c|}
\hline Study area & IG & $\mathrm{ZM}$ & Dom & TM & $\overline{\mathrm{Coz}}$ \\
\hline Number of plots & 4 & 5 & 3 & 4 & 2 \\
\hline $\begin{array}{l}\text { Mean plot altitude } \\
{[\mathrm{m} \text { a.s.1.] }}\end{array}$ & 289 & 204 & 593 & 469 & 368 \\
\hline Soil type* & $\begin{array}{l}\text { Cambisol and } \\
\text { Rendzic Leptosol }\end{array}$ & $\begin{array}{r}\text { Luvisol and } \\
\text { Cambisol }\end{array}$ & $\begin{array}{l}\text { Rendzic } \\
\text { Leptosol }\end{array}$ & $\begin{array}{r}\text { Luvisol and } \\
\text { Calcaric } \\
\text { Leptosol }\end{array}$ & Lithic Leptosol \\
\hline$T\left[{ }^{\circ} \mathrm{C}\right]$ & 10.2 & 10.5 & 8.7 & 8.4 & 9.4 \\
\hline$T_{\mathrm{Jul}}\left[{ }^{\circ} \mathrm{C}\right]$ & 20.3 & 20.5 & 18.6 & 18.4 & 19.6 \\
\hline$T_{\text {Jan }}\left[{ }^{\circ} \mathrm{C}\right]$ & -0.9 & -1.6 & -2.2 & -4.0 & -3.1 \\
\hline Prec $[\mathrm{mm}]$ & 669 & 625 & 739 & 620 & 618 \\
\hline$T_{\text {May-Sep }}\left[{ }^{\circ} \mathrm{C}\right]$ & 18.1 & 18.4 & 16.5 & 16.3 & 17.6 \\
\hline $\operatorname{Prec}_{\text {May-Sep }}[\mathrm{mm}]$ & 340 & 325 & 395 & 378 & 359 \\
\hline$E Q$ & 30.34 & 32.80 & 25.17 & 29.68 & 31.72 \\
\hline$I D M_{\text {Year }}$ & 33.11 & 30.49 & 39.52 & 33.70 & 31.86 \\
\hline$I D M_{\text {May-Sep }}$ & 12.10 & 11.44 & 14.91 & 14.37 & 13.01 \\
\hline Climate class (K-G) & $\mathrm{Cfb}$ & $\mathrm{Cfb}$ & $\mathrm{Cfb}$ & $\mathrm{Dfb}$ & $\mathrm{Dfb}$ \\
\hline $\begin{array}{l}\text { Climate class } \\
I D M_{\text {May-Sep }}\end{array}$ & $\begin{array}{r}\text { Slightly sub- } \\
\text { continental }\end{array}$ & $\begin{array}{r}\text { Moderately sub- } \\
\text { continental }\end{array}$ & $\begin{array}{r}\text { Slightly sub- } \\
\text { atlantic }\end{array}$ & $\begin{array}{r}\text { Slightly sub- } \\
\text { atlantic }\end{array}$ & $\begin{array}{r}\text { Slightly sub- } \\
\text { continental }\end{array}$ \\
\hline
\end{tabular}

Note. Abbreviations: IG - Iron Gates Natural Park, ZM - Zarand Mts, Dom - Domogled National Park, TM - Târnava Mare, Coz - Cozia National Park; $T$ - mean annual temperature, $T_{J u l}$ - mean temperature in July, $T_{J a n}$ - mean temperature in January, $T_{\text {May-Sep }}$ - mean temperature May to September, Prec - annual precipitation sum, Prec $c_{\text {May-Sep }}$ precipitation sum from May to September, $E Q$ - Ellenberg's Quotient, $I D M_{\text {year }}$ - DeMartonne Index whole year, $I D M_{\text {May-Sep }}$ - DeMartonne Index May to September for the mean plot altitude, climate class (K-G) the Köppen-Geiger climate classification. 
slightly $<30$ (Table 1 ).

$I D M$ is an aridity index calculated with the annual precipitation and mean annual temperature, $I D M_{\text {Year }}=\operatorname{Prec} /(T+10)$, and in equivalent form with the precipitation and temperature values from May to September, $I D M_{\text {May-Sep }}=$ $\operatorname{Prec}_{\text {May-Sep }} /\left(T_{\text {May-Sep }}+10\right)$. All study regions can be classified as humid with $I D M_{\text {Year }}>30$. IDMMay-Sep between 14-12 characterizes IG and $\mathrm{Coz}$ as slightly sub-continental, ZM between 12-10 as moderately sub-continental, and $\mathrm{TM}$ and

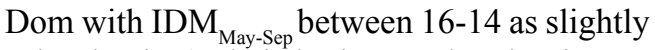
sub-atlantic (Arbeitskreis Standortskartierung 2016, Table 1).

\section{Vegetation types and data sampling}

The plots surveyed in the IG and at the foothills of ZM represent mixed oak forests with transitions to more mesic oak-hornbeam and hornbeam-beech forests on north-facing slopes and in shaded hollows. The plots at TM represent mesic oak-hornbeam and hornbeam-beech forests on shady slopes. In Dom and Coz we studied pine stands. At Dom we focused on relict populations of the drought adapted autochthonous Banat black pine (Pinus nigra var. banatica) on exposed limestone cliffs with shallow xero-rendzinas. The area displays a paragon of extra- and azonal vegetation (Pătroescu et al. 2007). At Coz two Pinus sylvestris stands were studied.

The regions were characterized by different land-use histories. Forest vegetation in IG was worst affected by site degradation and forest disturbance often as a result of grazing that was visible in the adjacent pasture-shibljak complex. Gully erosion on hillsides was often a result of over-grazing. In addition, a gypsy moth infestation in May 2013 caused by two consecutive years with low rainfall led to further disturbance. High abundances of Carpinus orientalis (Horvat et al. 1974), of grazing indicators (e.g. Holcus lanatus, Hieracium pilosella, Prunella vulgaris) and of species of nutrient-rich forest clearings (e.g. Dactylis glomerata, Fallopia dumetorum, Galium aparine) characterized disturbed sites. The deciduous forests at $\mathrm{ZM}$ represented the first tree generation after conversion of low coppice forests towards high forests in 1948. The studied forests at TM are part of the traditional rural landscape of Transylvania with forest, wood-pasture and open areas. However, in contrast to IG, decisive indications of site degradation and forest disturbance were not visible. Pine stands at steep rocky slopes in Dom and $\mathrm{Coz}$ were exposed to climate extremes and were susceptible to fire. The Black Pines at Dom are autochthonous and strictly protected from regular forest management. The Scots pine stands at Coz were probably planted. They occur at steep south facing siliceous rocky slopes that showed fire traces. Grassland owners often start fires intentionally that affect surrounding forests.

In the five regions we conducted 18 vegetation relevés, on plots of $200 \mathrm{~m}^{2}$ each (Table 1). The nomenclature of plant taxa follows $\mathrm{Eu}-$ ro+Med (Euro+Med (2006-). For genera not yet treated there (Acer, Actaea, Circaea, Clematis, Euonymus, Epilobium, Fallopia, Helianthemum, Helleborus, Linum, Pinus, Sambucus, Scabiosa, Tilia and Viola) we follow Ciocârlan (2009). Species were recorded separately for the tree layer (woody plants $>5 \mathrm{~m}$; separated into tree layers 1 and 2 in stands with clear stratification), shrub layer (woody plants $<5$ $\mathrm{m}>1 \mathrm{~m}$ ) and herb layer (woody plants $<1$ $\mathrm{m}$ and non-woody vascular plants). Total cover values per layer were recorded in percent, single species cover-abundances according to the modified scale of Braun-Blanquet. For data analysis, scale values were transformed into percent: $\mathrm{r}=0.1 ;+=0.5 ; 1=2.5 ; 2 \mathrm{~m}=5 ; 2 \mathrm{a}=$ $10 ; 2 b=20 ; 3=37.5 ; 4=62.5 ; 5=87.5$ (see Dierschke 1994; van der Maarel \& Franklin 2013).

\section{Data analysis}

We first classified the understorey vegetation into groups with similar species composition (hereafter community groups) using a hier- 
archical cluster analysis ( $\mathrm{R}$ function hclust, package stats, with Bray-Curtis distance and Ward's method with squared dissimilarities; Murtagh \& Legendre 2014) based on all species of the herb and shrub layers, i. e. plants of $<5 \mathrm{~m}$ in height. We used presence/absence data for understorey classification to avoid an overrating of high cover and dominant plants. The community groups were characterized according to (i) cover and species richness of the tree, shrub and herb layer, (ii) unweighted environmental indicator values (EIV) according to Borhidi (1995) and (iii) the climate variables $T, T_{\text {Jan }}, T_{\text {Jul }}, T_{\text {May-Sep }}$ Prec, Prec $_{\text {May-Sep, }}$ $E Q, I D M_{\text {Year }}, I D M_{\text {May-Sep }}$, and altitude (m a.s.l.). The EIV of Borhidi (1995) are estimates of the ecological optimum of plant species regarding continentality, light, nitrogen, soil reaction and temperature along 9-point scales for each parameter, and of moisture along a 12-point scale. Plant species with EIV 1 are indicators of dry, oceanic, shady, nutrient-poor, acidic or cold conditions, respectively, while plant species with EIV 9 (or 12) indicate the opposite extreme. All variables were compared among community groups using ANOVA or the Kruskal-Wallis-H-test when data were not normally distributed followed by the adequate post-hoc-tests.

To visualize differences in total species composition when abundance of species is taken into account we conducted non-metric multidimensional scaling (NMDS on two dimensions with Bray-Curtis distance, r-function metaMDS, R package vegan). The climate variables and EIV were fitted to the ordination axes to evaluate their influence on species composition (function envfit). A relation of understorey and canopy tree species composition was investigated with Mantel-tests to evaluate if distance in understorey species composition (Bray-Curtis distance) is reflected in canopy tree species composition. We regarded presence/absence data as well as abundance data (= cover value in \%) for all vegetation plots and for deciduous forest plots only. If a species occurred in different vegetation layers 224 the highest cover value was used. The cover of each tree species was determined for each community group and compared using ANOVA or Kruskal-Wallis, respectively.

For three widespread tree species (Fagus sylvatica, Quercus petraea and Pinus sylvestris), we calculated the climatic marginality index (CMI, Mellert et al. 2015), developed as a metric for site specific susceptibility of a forest to climate change and based on generalized additive models with variable selection (Falk \& Mellert 2011), involving Worldclim data (Hijmans et al. 2005: 1a - summer precipitation from June to August; $1 \mathrm{~b}$ - precipitation in the vegetation period (May to September); 2 - mean temperature in the vegetation period; 3 - mean temperature in January) at each plot site. For $C M I_{\mathrm{Fag}}$ (climatic marginality index for $F$. sylvatica) the climate variables $1 \mathrm{~b}, 2$ and 3 were considered, for $P$. sylvestris $\left(C M I_{\mathrm{Pin}}\right)$ and for $Q$. petraea $\left(C M I_{\text {Que }}\right)$ the variables $1 \mathrm{a}, 2$ and 3. $C M I$ indicates the distance to the rear niche edge, i.e. the most xeric environment according to the $E Q$, and relates the probability of occurrence of a species at a site to a standard threshold of occurrence. Small, i.e. negative, $C M I$ values indicate environmental conditions within the niche (core and extended distribution zone of a species), while large (positive) values indicate conditions outside the niche of a species (occasional and no occurrence zone). We related the abundance of each of these tree species per plot to the corresponding CMI value calculated for the plot and to the climate variables $T$, Prec, $E Q, I D M_{\text {Year }}$ and $I D M_{\text {May-Sep }}$ using Spearman correlations. In addition, we grouped all occurring tree species into mesic and thermophilous species according to their EIV for temperature (mesic: EIV $\mathrm{T} \leq 6$; thermophilous: EIV $T \geq 7$ ). The abundance of both tree species groups per plot was related to the corresponding $C M I$ for $F$. sylvatica, $Q$. petraea and $P$. sylvestris at each plot and to the other climate variables for all vegetation plots and deciduous forest plots only. 


\section{Results}

\section{Classification of understorey species compo- sition}

Cluster analysis based on presence/absence of understorey plant species reflected the five study regions (Figure 1). The first subdivision separated the five pine forest plots from the 13 deciduous forest plots. The long-branched subdivision of the stands with Pinus nigra var. banatica and $P$. sylvestris, respectively, indicated a high degree of understorey dissimilarity between them. The first subdivision of the deciduous forests separated four plots in TM on shady slopes with relatively low temperatures and high summer precipitation from the rest. Based on the understorey classification we defined three community groups: pine forests (five plots), moderately mesic deciduous forests (four plots) and thermophilous deciduous forests (nine plots; Figure 1).

Both deciduous forest groups had a higher tree layer cover and tree species richness than the pine forests. They were characterized by higher EIV for moisture and lower EIV for reaction (Table 2). Pine and thermophilous deciduous forests had higher EIV for temperature than the mesic deciduous forests, while all three groups showed a gradient in light and nitrogen availability with the mesic and pine forests representing the EIV extremes. The thermophilous deciduous forests are located at the lowest elevation and are characterized by an $E Q>30$. Mesic deciduous and pine forests had an $E Q<30$. Standard errors were, however, high for pine forests regarding $E Q$, Prec and altitude as the plots in Dom characterized by Pinus nigra var. banatica (north facing slopes at altitudes of $593 \mathrm{~m}$, climate class Cfb) differed much from plots in Coz with $P$. sylvestris (south facing slopes at $368 \mathrm{~m}$, climate class Dfb; see Table 1). This was confirmed by NMDS results which showed a clear separation of Pinus nigra var. banatica and P. sylvestris forests along the second axis (Figure 3A-C). According to axis correlations with climatic variables and EIV, the first ordination axis separated the study regions and hence chiefly pine and deciduous forests. This can be explained both by different regional species pools and by environmental factors such as low nutrient availability and dry conditions on shallow soils (in spite of relatively high precipitation) as well as high light availability caused by an open canopy in both types of pine forest (Figure 2A; Table 2). The second NMDS axis represents a climate gradient. Plots with positive axis scores were characterized by highest altitude and $I D M_{\text {May-Sep }}$ and lowest temperatures and $E Q$ s. $C M I_{\mathrm{Pin}}, C M I_{\mathrm{Fag}}$ and $C M I_{\text {Que }}$ correlated negatively with the second axis, with the lowest fit found for $C M I_{\text {Que }}$.

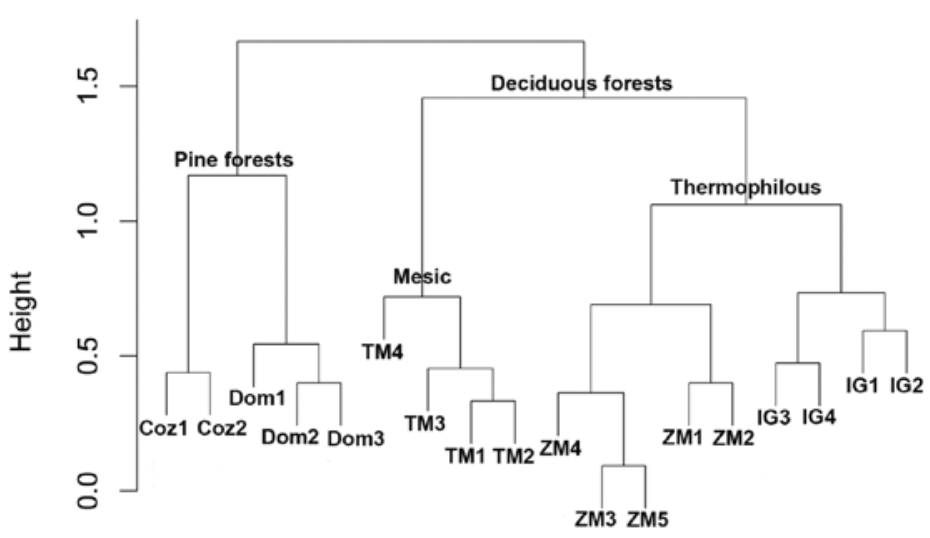

\section{Figure 1}

Dendrogram with community groups based on presence/ absence of understorey plant species using Bray-Curtis distance and Ward's method with squared dissimilarities. The Plot ID gives the region and the plot number within the region (e.g. IG3 = plot 3 in Iron Gates Natural Park). 'Height' indicates the floristic distance at which clusters were formed. 
Table 2 Characterization of the community groups according to vegetation layer cover values expressed as a percentage, species numbers per plot, environmental indicator values (EIV; Borhidi 1995), and climatic variables calculated per plot.

\begin{tabular}{|c|c|c|c|}
\hline \multirow[b]{3}{*}{$n$} & \multicolumn{2}{|l|}{ Deciduous forest } & \multirow[t]{2}{*}{ Pine forest } \\
\hline & Thermophilous & $\overline{\text { Mesic }}$ & \\
\hline & 9 & 4 & 5 \\
\hline \multicolumn{4}{|l|}{ Cover values [\%] } \\
\hline Tree layer & $73.7 \pm 2.1^{\mathrm{a}}$ & $83.0 \pm 3.9^{\mathrm{a}}$ & $28.2 \pm 5.0^{\mathrm{b}}$ \\
\hline Shrub layer & $12.9 \pm 4.7$ & $0.4 \pm 0.4$ & $15.1 \pm 6.3$ \\
\hline Herb layer & $32.7 \pm 7.5$ & $53.8 \pm 9.0$ & $60.0 \pm 6.5$ \\
\hline \multicolumn{4}{|c|}{ Species numbers [n/plot] } \\
\hline Tree layer & $3.3 \pm 0.3^{\mathrm{a}}$ & $3.5 \pm 0.3^{\mathrm{a}}$ & $1.2 \pm 0.2^{\mathrm{b}}$ \\
\hline Shrub layer & $3.6 \pm 0.8$ & $1.0 \pm 0.0$ & $3.6 \pm 1.3$ \\
\hline Herb layer & $30.2 \pm 2.4$ & $41.0 \pm 7.2$ & $40.2 \pm 4.7$ \\
\hline \multicolumn{4}{|l|}{ EIV } \\
\hline Moisture & $4.8 \pm 0.1^{\mathrm{a}}$ & $5.5 \pm 0.2^{\mathrm{a}}$ & $3.7 \pm 0.1^{\mathrm{b}}$ \\
\hline Continentality & $4.2 \pm 0.1$ & $3.9 \pm 0.0$ & $4.3 \pm 0.1$ \\
\hline Light & $5.2 \pm 0.1^{\mathrm{a}}$ & $4.4 \pm 0.2^{\mathrm{b}}$ & $6.9 \pm 0.2^{\mathrm{c}}$ \\
\hline Nitrogen & $4.4 \pm 0.2^{\mathrm{a}}$ & $5.3 \pm 0.3^{\mathrm{b}}$ & $3.3 \pm 0.1^{\mathrm{c}}$ \\
\hline Reaction & $6.3 \pm 0.1^{\mathrm{a}}$ & $6.5 \pm 0.1^{\mathrm{a}}$ & $6.9 \pm 0.1^{\mathrm{b}}$ \\
\hline Temperature & $6.2 \pm 0.1^{\mathrm{a}}$ & $5.5 \pm 0.1^{\mathrm{b}}$ & $6.2 \pm 0.1^{\mathrm{a}}$ \\
\hline \multicolumn{4}{|l|}{ Climatic variables } \\
\hline altitude [m a.s.l.] & $240 \pm 17^{\mathrm{a}}$ & $469 \pm 9^{b}$ & $503 \pm 57^{b}$ \\
\hline$T_{\mathrm{Jan}}\left[{ }^{\circ} \mathrm{C}\right]$ & $-1.3 \pm 0.1^{\mathrm{a}}$ & $-4.0 \pm 0.2^{\mathrm{b}}$ & $-2.6 \pm 0.2^{c}$ \\
\hline$T\left[{ }^{\circ} \mathrm{C}\right]$ & $10.3 \pm 0.1^{\mathrm{a}}$ & $8.4 \pm 0.0^{\mathrm{b}}$ & $9.0 \pm 0.2^{\mathrm{c}}$ \\
\hline$T_{\mathrm{Jul}}\left[{ }^{\circ} \mathrm{C}\right]$ & $20.4 \pm 0.1^{\mathrm{a}}$ & $18.4 \pm 0.1^{\mathrm{b}}$ & $19.0 \pm 0.3^{\mathrm{b}}$ \\
\hline$T_{\text {May-Sep }}$ & $18.3 \pm 0.1^{\mathrm{a}}$ & $16.3 \pm 0.1^{b}$ & $16.9 \pm 0.3^{\mathrm{b}}$ \\
\hline $\begin{array}{l}\text { May-sep } \\
\text { Prec }[\mathrm{mm}]\end{array}$ & $644 \pm 8^{\mathrm{ab}}$ & $621 \pm 2^{\mathrm{a}}$ & $692 \pm 30^{\mathrm{b}}$ \\
\hline $\operatorname{Prec}_{\text {May-Sep }}[\mathrm{mm}]$ & $332 \pm 3^{a}$ & $378 \pm 1^{\mathrm{b}}$ & $380 \pm 9^{b}$ \\
\hline$E Q$ & $31.8 \pm 0.5^{\mathrm{a}}$ & $29.6 \pm 0.2^{\mathrm{ab}}$ & $27.8 \pm 1.7^{\mathrm{b}}$ \\
\hline$I D M_{\text {Year }}$ & $31.7 \pm 0.5$ & $33.7 \pm 0.2$ & $36.5 \pm 1.9$ \\
\hline$I D M_{\text {May-Sep }}$ & $11.7 \pm 0.1^{\mathrm{a}}$ & $14.4 \pm 0.1^{\mathrm{b}}$ & $14.2 \pm 0.5^{\mathrm{b}}$ \\
\hline
\end{tabular}

Note. Given are mean values \pm standard error. Letters $(a, b, c)$ specify significant differences between community groups. Values with no letters did not differ significantly between community groups.

The NMDS diagram also displays mesoclimate-related gradients in species composition. In TM, for instance, the plots 1 to 3 were located at low to intermediate slope positions, while plot 4 was situated on the more exposed hill top. Accordingly, the vegetation showed a slight transition from mesic to thermophytic conditions expressed by decreasing second axis scores. Similar gradients were found in regions $\mathrm{IG}$ and $\mathrm{ZM}$ where the low slope plots (ZM1, ZM2) and the north facing plot (IG3) 226 were less thermophytic with increasing plot scores along the second axis.

\section{Linkage between understorey and canopy tree species composition}

Based on Bray-Curtis dissimilarity of species abundance data and 999 permutations we found a significantly positive Mantel correlation between the dissimilarities in understorey and canopy tree species composition, both for 

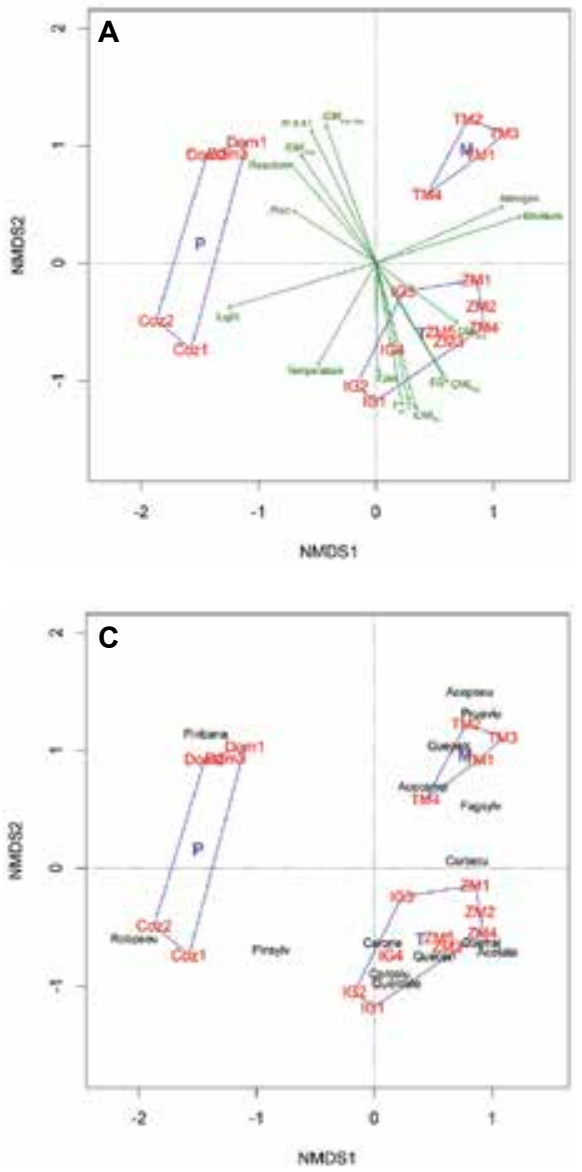

all plots $\left(r_{\text {Mantel }}=0.697, \mathrm{p}=0.001\right)$ and for deciduous forest plots only $\left(r_{\text {Mantel }}=0.637, p=\right.$ 0.001 ). The relationship was stronger for presence/absence data (all plots: $r_{\text {Mantel }}=0.829, p$ $=0.001$; deciduous forest plots: $r_{\text {Mantel }}=0.756$, $p=0.001)$. While several tree and understorey species characterized the three community groups, some species took an intermediate position either along the first or second NMDS axis (Figure 2B-C). P. sylvestris dominated the tree layer in plots sampled in $\mathrm{Coz}$ and was also recorded in IG2 and IG4. Fagus sylvatica and Carpinus betulus took intermediate positions between the mesic and thermophilous deciduous forests (Figure 2B). In the understorey $(<$

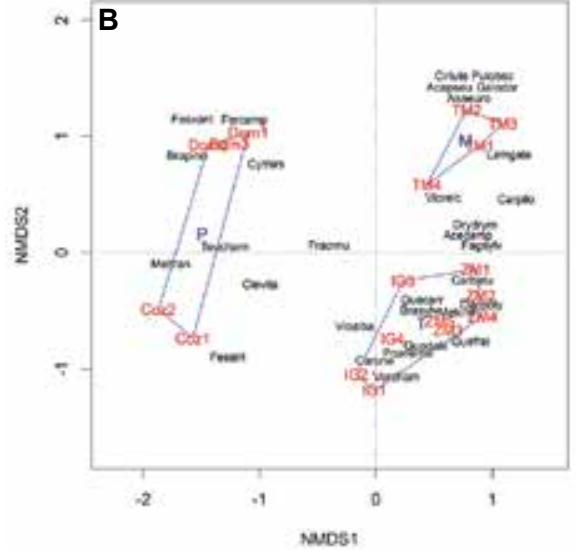

\section{Figure 2}

NMDS diagrams of species abundance data (stress $=0.137$ ) with $\mathrm{A}$ ) climate variables and EIV fitted to the first two ordination axes with $p<0.05$, B) species scores of tree layer species $(>5 \mathrm{~m})$ and $\mathrm{C}$ ) species scores of understorey species $(<5 \mathrm{~m})$ with a mean cover of $>0.5 \%$ across all plots and an occurrence in at least 3 plots. The blue lines show the results of the cluster analyses based on presence-absence data of all vegetation plots with $\mathrm{P}$ - Pine forests, M - Mesophilous deciduous forests and $\mathrm{T}$ - Thermophilous deciduous forests. The Plot ID represents the region and the plot number in that region. For species abbreviations see Tables 3 and 4 .

$5 \mathrm{~m}$ in height) both tree species were closer associated with the thermophilous community group (Figure 2B). Drymochloa drymeja (more commonly named Festuca drymeja; see www.theplantlist.org) had an intermediate position between the deciduous forest groups (Máliš et al. 2013). The drought-resistant and light-demanding Fraxinus ornus linked pine and deciduous forests (see Table 3 and Supporting Information III for complete vegetation survey data).

Each deciduous forest community group was characterized by six prevalent tree species (Table 3 ). However, only $Q$. cerris and $Q$. petraea differ significantly in cover values 
Table 3 Tree species abundances (mean cover \pm standard error in \%) in the three community groups and EIV of each tree species according to Borhidi (1995)

\begin{tabular}{|c|c|c|c|c|c|c|c|c|c|}
\hline \multirow[b]{3}{*}{$N$} & \multicolumn{2}{|c|}{ Deciduousforest } & \multirow{3}{*}{$\begin{array}{l}\text { Pine forest } \\
5\end{array}$} & \multicolumn{6}{|l|}{ EIV } \\
\hline & Thermophil. & Mesic & & $\mathrm{L}$ & $\mathrm{T}$ & $\mathrm{C}$ & $\mathrm{M}$ & $\mathrm{R}$ & $\mathrm{N}$ \\
\hline & 9 & 4 & & & & & & & \\
\hline \multicolumn{10}{|c|}{ Prevalent in thermophilous forests } \\
\hline Quercus dalechampii & $11.17 \pm 5.14$ & 0 & 0 & 6 & 7 & 6 & 4 & 6 & 2 \\
\hline Quercus frainetto & $5.57 \pm 2.42$ & 0 & 0 & 6 & 8 & 6 & 5 & 6 & 4 \\
\hline Corylus colurna & $1.12 \pm 1.11$ & 0 & 0 & . & . & . & 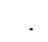 & . & . \\
\hline Acer tataricum & $0.39 \pm 0.27$ & 0 & 0 & 5 & 7 & 8 & 4 & 7 & 4 \\
\hline Carpinus orientalis & $5.83 \pm 4.10$ & 0 & $0.12 \pm 0.10$ & 6 & 9 & 6 & 4 & 8 & 4 \\
\hline Quercus cerris & $32.78 \pm 7.95^{\mathrm{a}}$ & $0.13 \pm 0.13^{\mathrm{b}}$ & $0.02 \pm 0.02^{\mathrm{b}}$ & 6 & 8 & 4 & 5 & 6 & 4 \\
\hline \multicolumn{10}{|l|}{ Prevalent in mesic forests } \\
\hline Quercus petraea & $0 \mathrm{a}$ & $12.13 \pm 8.75 b$ & $0^{\mathrm{a}}$ & 6 & 6 & 4 & 5 & 5 & 2 \\
\hline Carpinus betulus & $15.00 \pm 4.98^{\mathrm{ab}}$ & $36.38 \pm 15.60^{\mathrm{a}}$ & $0^{\mathrm{b}}$ & 4 & 6 & 4 & 6 & 6 & 5 \\
\hline Acer campestre & $0.79 \pm 0.33^{\mathrm{ab}}$ & $3.38 \pm 2.26^{\mathrm{a}}$ & $0^{\mathrm{b}}$ & 5 & 7 & 6 & 5 & 7 & 5 \\
\hline Fagus sylvatica & $5.40 \pm 4.16^{\mathrm{ab}}$ & $30.00 \pm 19.50^{\mathrm{a}}$ & $0.02 \pm 0.02^{\mathrm{b}}$ & 3 & 5 & 2 & 5 & 7 & 5 \\
\hline Prunus avium & $0.50 \pm 0.26$ & $5.25 \pm 2.74$ & $0.22 \pm 0.16$ & 4 & 6 & 4 & 6 & 7 & 5 \\
\hline Acer pseudoplatanus & 0 & $3.75 \pm 2.17$ & $0.52 \pm 0.50$ & 4 & 5 & 4 & 6 & 6 & 7 \\
\hline \multicolumn{10}{|l|}{ Prevalent in pine forests } \\
\hline Pinus nigra var. banatica & 0 & 0 & $22.50 \pm 9.19$ & 7 & 8 & 4 & 4 & 9 & 2 \\
\hline Robinia pseudoacacia & 0 & 0 & $2.10 \pm 1.98$ & 5 & 7 & 4 & 4 & 7 & 8 \\
\hline Pinus sylvestris & $3.33 \pm 2.36$ & 0 & $15.00 \pm 9.19$ & 7 & 4 & 7 & 4 & 5 & 2 \\
\hline$C M I_{\text {Fag }}$ & $-0.015 \pm 0.095^{a}$ & $-0.606 \pm 0.087^{b}$ & $-1.318 \pm 0.468^{b}$ & & & & & & \\
\hline$C M I_{\text {Que }}$ & $-1.666 \pm 0.068$ & $-1.601 \pm 0.016$ & $-1.965 \pm 0.169$ & & & & & & \\
\hline$C M I_{\text {Pin }}$ & $0.685 \pm 0.047^{\mathrm{a}}$ & $-0.480 \pm 0.084^{\mathrm{b}}$ & $-0.386 \pm 0.223^{b}$ & & & & & & \\
\hline
\end{tabular}

Note. Abbreviations. EIV: L - Light, T - Temperature, C - Continentality, M - Moisture, R - Reaction, N - Nitrogen). Given are also mean climatic marginality indices for Fagus sylvatica, Quercus petraea and Pinus sylvestris $\left(C M I_{F a g^{\prime}} C M I_{Q u e^{\prime}} C M I_{P i n}\right)$. Letters indicate significant differences between community groups. Tree species with no letters did not differ significantly between community groups. Species name letters in bold represent abbreviations used in NMDS (see Figure 3B-C).

in the thermophilous or mesic group, respectively. Q. dalechampii, Q. frainetto, Corylus colurna, Carpinus orientalis and Acer tataricum were exclusively recorded in plots of the thermophilous community group. Pinus nigra var. banatica and the invasive alien tree species Robinia pseudoacacia, often cultivated for land reclamation and site amelioration in Romania (Enescu \& Dănescu 2013), occurred only in the pine forests (Table 3). Tree species prevalent in the thermophilous community group are generally characterized by higher light, temperature and continentality and lower moisture and nitrogen values compared to the tree species that were more abundant in the 228 mesic community group. Except for moisture, the tree species of the pine forests are rather heterogeneous in their environmental indicator values.

\section{Relationship between tree species abun- dance and climate variables}

With $C M I_{\text {Que }}$ values of $<-1.6$, plots of all three community groups are characterized by environmental conditions within the niche of Quercus petraea (Table 3). For Fagus sylvatica the $C M I_{\text {Fag }}$ indicates niche edge conditions in plots of the thermophilous community group with values close to zero. Both, mesic and pine for- 
Table 4 Spearman correlation coefficients between climate variables and cover of tree species and tree species groups (in \%) in all plots and in deciduous forest plots only

\begin{tabular}{|c|c|c|c|c|c|c|c|c|}
\hline & $C M I_{F a g}$ & $C M I_{\text {Que }}$ & $C M I_{\text {Pin }}$ & $T\left[{ }^{\circ} \mathrm{C}\right]$ & $\begin{array}{l}\text { Prec } \\
{[\mathrm{mm}]}\end{array}$ & $E Q$ & $I D M_{\text {Year }}$ & $I D M_{\text {May-Sep }}$ \\
\hline \multicolumn{9}{|l|}{ All plots $(\mathrm{n}=18)$} \\
\hline Fagus sylvatica & -0.227 & & & -0.249 & -0.371 & -0.047 & 0.004 & 0.025 \\
\hline Quercus petraea & & 0.325 & & $-0.701 * *$ & $-0.493 *$ & -0.318 & 0.273 & 0.417 \\
\hline Q. petraea $+Q$. dalechampii & & 0.169 & & 0.139 & -0.196 & 0.179 & -0.173 & -0.303 \\
\hline Pinus sylvestris & & & 0.103 & 0.021 & -0.004 & 0.080 & -0.056 & -0.021 \\
\hline Mesic trees & -0.114 & 0.328 & -0.224 & -0.296 & $-0.486 *$ & 0.027 & -0.074 & -0.003 \\
\hline Thermophilous trees & $0.847 * * *$ & 0.450 & $0.955 * * *$ & $0.751 * * *$ & -0.123 & $0.650 * *$ & $-0.625 * *$ & $-0.818 * * *$ \\
\hline \multicolumn{9}{|l|}{ Deciduous plots $(n=13)$} \\
\hline Fagus sylvatica & $-0.656^{*}$ & & & -0.461 & -0.450 & -0.329 & 0.234 & 0.424 \\
\hline Quercus petraea & & 0.113 & & $-0.809 * * *$ & $-0.570 *$ & $-0.641 *$ & $0.566 *$ & $0.809 * * *$ \\
\hline Q. petraea $+Q$. dalechampii & & -0.341 & & -0.119 & 0.209 & -0.209 & 0.240 & 0.204 \\
\hline Pinus sylvestris & & & 0.115 & -0.092 & $0.547^{*}$ & -0.215 & 0.276 & 0.092 \\
\hline Mesic trees & $-0.612 *$ & 0.085 & $-0.824 * * *$ & -0.546 & $-0.767 * *$ & -0.281 & 0.182 & 0.447 \\
\hline Thermophilous trees & $0.880 * * *$ & 0.283 & $0.975^{* * *}$ & $0.684 * *$ & 0.588* & 0.466 & -0.411 & $-0.610 *$ \\
\hline
\end{tabular}

Note. Abbreviations: $* p<0.05, * * p<0.01, * * * p<0.001$. Significant correlations with $\mathrm{p}<0.05$ are printed in bold. Mesic trees represent all tree species with EIV T $\leq 6$; thermophilous trees represent all tree species with EIV $\mathrm{T} \geq 7$.

est plots are within the climatic niche of F. sylvatica with lowest $C M I_{\text {Fag }}$ values calculated for the study plots dominated by Pinus nigra var. banatica (-1.9 to -2.3$)$. The plot-based $C M I_{\text {Pin }}$ shows conditions outside the species' niche in thermophilous forests, whereas plots of both other community groups would be within the niche. However, both plots dominated by $\mathrm{Pi}$ nus sylvestris in Coz are characterized by $C M I$ Pin values $>0(0.13)$.

Correlations between climate variables and abundances of the tree species showed that $C M I_{\text {Fag }}$ and $C M I_{\text {Pin }}$ were highly positively correlated with the abundance of thermophilous deciduous tree species (= cumulative abundance of tree species with EIV $\mathrm{T} \geq 7$ ) in all plots. In deciduous forests the relationship was even stronger (Table 4). Weaker positive correlations were detected between thermophilous deciduous species abundance and $T, E Q$ (for all plots) and Prec (for deciduous plots). Significant negative correlations were detected with the $I D M_{\text {May-Sep }}$ and $I D M_{\text {Year }}$ (for all plots). Mesic tree species abundance (= cumulative abundance of tree species with EIV $\mathrm{T} \leq 6$ ) in all plots showed no dependency with climate variables (except a negative correlation with Prec). In deciduous forests the abundance of mesic trees was negatively correlated with the $C M I_{\text {Pin }}$, Prec and the $C M I_{\mathrm{Fag}}$.

Quercus petraea showed significant negative correlations with $T$, Prec, and $E Q$ (the latter only for deciduous plots). For deciduous forest plots there was also a strong positive correlation between $Q$. petraea and IDM $M_{\text {May-Sep }}$ and a weak one between oak abundance and $I D M_{\text {Year }}$. No significant correlations were found with Quercus petraea s.l., which includes both $Q$. petraea (s.str.) and $Q$. dalechampii. Within deciduous forest plots, the abundance of $\mathrm{Fa}$ gus sylvatica showed a negative relationship with $C M I_{\text {Fag }}$. The positive correlation between P. sylvestris and Prec in deciduous forests was based on two occurrences only.

Highest cover of Fagus sylvatica in deciduous forest plots was found at plots with climatic conditions inside its niche range $\left(C M I_{\mathrm{Fag}}\right.$ $<0$; Figure 4A). Plot positions are, however, 
all marginal considering the defined niche of Fagus sylvatica in Central Europe. There is no such clear relationship with $E Q$, although an $E Q$ of 30 is generally seen as a range limit for climatic climax communities of $F$. sylvatica. F. sylvatica abundance peaked twice, at $E Q=29.5$ and at $E Q=33$ (Figure 3A). When focusing on the abundance of combined mesic and thermophilous deciduous tree species, both species groups showed opposing trends along the $C M I_{\text {Fag }}$ with significant $\mathrm{R}^{2}$-values for both groups (Figure 3B). There was no such significant relationship with $E Q$. While mesic trees occurred at an $E Q$ of 33 with cover up to $60 \%$, thermophilous tree species showed similar abundance at an $E Q<30$ (Figure 3B).

\section{Discussion}

\section{Species composition of pine forests}

As demonstrated using ecological indicator values, both climatic and edaphic differences among regions in western Romania were clearly reflected in the understorey and canopy
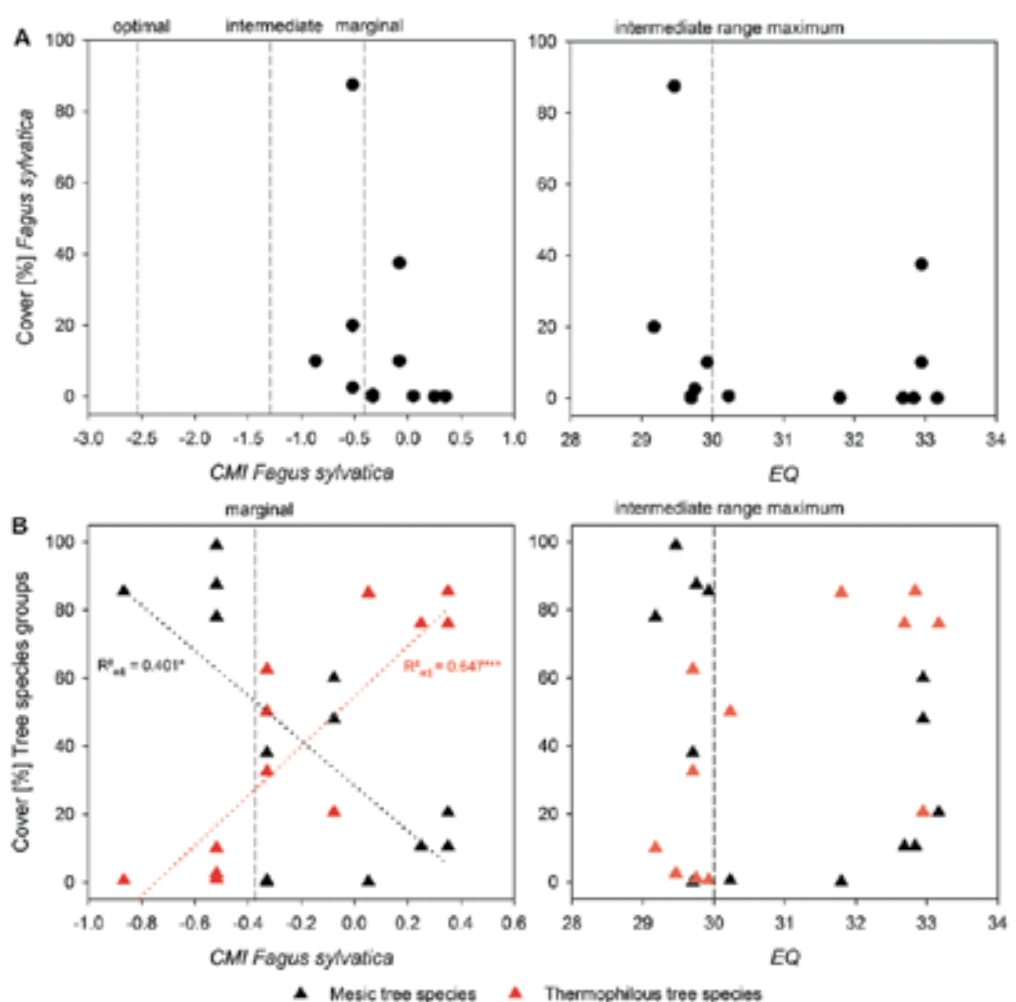

Figure 3 Relationship between the climatic marginality index (CMI) of Fagus sylvatica and the Ellenberg Quotient (EQ) and A) the cover of Fagus sylvatica and B) the cover of mesic and thermophilous tree species in all vegetation plots dominated by deciduous tree species $(n=13)$. The dashed lines indicate an optimal, an intermediate and a marginal position according to the CMI (Mellert et al. 2015) or the intermediate range maximum according to the $E Q$ (Mellert et al. 2016) for the niche of Fagus sylvatica in Central Europe. The dotted lines show the regression lines for significant regressions with $* p<0.05$ and $* * * p<0.001$. 
tree species composition. Thus, vegetation surveys can be used as indicator for abiotic conditions. Even though relevant climatic variables in the vegetation period such as $T_{\text {Jul }}$, Prec May-Sep, $T_{\text {May-Sep }}$ or $I D M_{\text {May-Sep }}$ do not differ between the mesic forest community group and the pine forest group, the characterization of the understorey vegetation with environmental indicator values of Borhidi (1995) clearly reflected the dry, nutrient-poor and shallow soils (both leptosols) of the slopes dominated by pines in the Domogled and Cozia National Park. Under extreme soil conditions the canopy cover is low and the occurrence and abundance of light-demanding species and drought indicators is high. A missing precipitation signal on tree growth for Pinus nigra and P. sylvestris in the Mediterranean region, at the drought limits of the species' distribution, underlines the importance of edaphic factors for the occurrence of pine species in western Romania (Herrero et al. 2013). Distinct compositional differences between the pine-dominated sites are likely to be related to the calcareous bedrock of the P. nigra var. banatica stands in contrast to the siliceous bedrock of the $P$. sylvestris stands, which is also reflected in the EIV for reaction that were positively related to the black pine stands. However, also climate variables differentiate between the pine forest groups. Generally, the Mediterranean-montane $P$. nigra occurs at warmer and drier sites (e.g. sun-exposed slopes) than the sub-boreal $P$. sylvestris that is often more frequent in warm summer continental climate (Rouget et al. 2001, Herrero et al. 2013). The Domogled National Park with its $P$. nigra stands is climatically fairly similar to the Târnava Mare with its mesic beech and beech-hornbeam forests. In contrast, the investigated $P$. sylvestris stands near the mouth of the Lotru River in the Olt valley, surrounded by thermophilous oak forests, are geomorphologically, geologically and climatically similar to inner-Alpine dry valleys (cf. Rigling et al. 2013). P. nigra expanded from its Mediterranean distribution center to the north in the interglacials and established at similar warm, calcareous sites. Geographical isolation supported the differentiation of var. banatica from the Mediterranean stock. During the last glaciation the area decreased and comprises now disjunct populations in only three distant areas of Romania (Pătroescu et al. 2007). The main range in the Domogled area is between 550 to $750 \mathrm{~m}$ a.s.1. in north-western exposition and black pine is therefore associated with mesic beech forests at less inclined low-slope sites where the water supply is higher $\left(<18^{\circ}\right.$; Horvat et al. 1974, Pătroescu et al. 2007).

The $P$. sylvestris sites in the Cozia National Park are outside the calculated range margins for $P$. sylvestris. Its occurrence may thus be related to human impact of some kind and/ or to fire effects which are known to affect pine communities (Agee 1998, Hancock et al. 2005). Fire traces were detected at old pine trees (as well as at some of the old Black Pine trees in the Domogled National Park). Post-fire effects such as reduced competition and open litter-free soil may have facilitated Scots pine seedling establishment at the steep south-exposed warm and dry slopes (Castro et al. 2005). The seedlings may originate from scattered autochthonous pine trees at exposed cliffs of the Cozia National Park scenery. It seems plausible, that rocky areas served as glacial refugia and fire refugia for pine trees. Following this, exposed rocks and fire are important factors for their persistance. In contrast, the $P$. sylvestris occurrences of low vitality in the tree layer of thermophilous oak stands at the Iron Gate indicate no natural regeneration. These non-vital occurrences therefore underline the presence outside the estimated climatic niche of $P$. sylvestris and the reliability of calculated climatic marginality index values.

\section{Species composition of deciduous forests}

For deciduous forests, both canopy tree species and understorey composition reflect the climatic gradient among regions. Particularly, the differences in temperature variables contrast thermophilous oak forests strongly with 
mesic beech and oak-hornbeam forests. Seasonality is also important as precipitation in the vegetation period is significantly higher for the mesic community group, even though the annual precipitation sum is slightly higher for the thermophilous group. Opposing effects of annual and seasonal rainfall were also detected on species composition of the ecotone between Fagus sylvatica and Quercus pubescens in southern Germany (Gärtner et al. 2008) and on the distribution of different pine species in Catalonia, Spain (Rouget et al. 2001). The warm temperate climate in the western part of Romania, where $Q$. frainetto is abundant, is characterized by a distinct dry period in summer, which is missing in the cooler temperate climate of the east (Horvat et al. 1974).

Our results show that the modelled climatic marginality of beech at a plot site can reliably predict the abundance of mesic and thermophilic tree species (Mellert et al. 2016). Marginality of beech can therefore be used as a surrogate for predicting the suitability of a tree species on a site. For Fagus sylvatica itself, the calculated climatic marginality index clearly demonstrates the close distance to its rear edge range margin in western Romania at altitudes $<600 \mathrm{~m}$. The marginality thereby explains the beech occurrence better than the well introduced $E Q$, presumably due to the incorporation of rainfall in the vegetation period compared to the annual precipitation sum considered for the $E Q$. Moreover, the $E Q$ was not created to set an absolute limit of beech, but rather to determine the critical turning point, where zonal beech forest vegetation changes to zonal mixed oak forest/woodland ( $E Q>$ 30). The marginal character of the beech stands can also be deduced from the species richness in the tree layer. In western Central Europe older beech stands of mesic and mid-altitude conditions are generally monospecific due to the high competitiveness of beech (Hobi et al. 2015, Leuschner 2015, Schulze et al. 2016). The stands of the mesic community group sampled in Romania have all more than three tree species per plot indicating a lower compet232 itiveness of beech at these altitudes (Gärtner et al. 2008). In dry regions beech may even profit from other tree species. In a recent study it was shown that beech surrounded by interspecific neighbors were less affected by exceptionally dry years than in monospecific surroundings (Metz et al. 2016). This underlines the better adaptability of rear edge populations to warm and dry conditions and may be a further explanation for recent growth increases of beech at the rear edge (Tegel et al. 2014).

A climatic marginality index calculated for Q. petraea, another important forest tree in Central Europe, revealed that all investigated plots were within the niche range of this oak species. This might support the hypothesis that sessile oak will presumably benefit from climate change compared to beech (Mette et al. 2013). In the present study, though, Q. petraea (s.str.) was only associated with the mesic community and did not occur in the thermophilous group. This is in accordance with Coldea \& Pop (1996) who associate Q. petraea (s.str.) with moderately mesic forests. The highest abundance of $Q$. petraea (s.str.) was recorded in plot TM4 on a sun-exposed hill top, whereas hornbeam and beech dominated the tree layer at low to intermediate slope positions. Thus, forest stands of $Q$. petraea (s.str.) may characterize the transition zone between mesic and moderately thermophilous forests - i.e. with dominance of mesophilous plants. Even though $Q$. petraea (s.str.) was absent in the study plots in IG and ZM, it occurs in these regions (Pop et al. 1978; Matacă 2005) and missing occurrences are likely to represent a data gap. However, Q. petraea has often been treated in a broad sense including taxonomically and chorologically poorly understood microspecies of the Quercus petraea group such as Q. dalechampii or Q. polycarpa (Chytrý 1997, Roleček 2005, Indreica 2011), which appear to differ in their habitat requirements even though with a big overlapping zone (Borhidi 1995; Di Pietro et al. 2012). Competition and introgression effects of closely related oak taxa may also matter locally. Distribution 
models of tree species are often based on national inventories or phytosociological relevés that have treated species in a broad sense. This might question the modelled distribution of $Q$. petraea that requires a more distinct consideration of microspecies. In addition, sessile oak dominance in drier places in Central Europe is considered being rather the result of silviculture than climate-related (Dolos et al. 2016). According to Czúcz et al. (2011) 82 to $100 \%$ of zonal sessile oak forests might even be outside the climatic niche in 2050. This underlines the primarily semi-mesic character of sessile oak.

Beech was not uncommon in forests of moderately thermophilous character, both in the canopy and in the understorey. The role of beech often depends on mesoclimatic factors such as slope position (Horvat et al. 1974). In suitable sites beech forms extrazonal stands within the thermophilous oak forest zone dominated by Quercus cerris and $Q$. frainetto, indicating the approximate position of the drought-resistance limits of $F$. sylvatica (Bolte et al. 2007, Gärtner et al. 2008). Our results show that vegetation records can reveal the effect of mesoclimatic factors on species composition for identifying small-sized and isolated extrazonal niches (e.g. enclaves with increased humidity). We exemplarily estimated the direct radiation on plots of the Zarand Mountains taking into account altitude, aspect, slope inclination and an elevated horizon (Fischer \& Gilgen 2002). According to that, the most mesic plot (ZM1) received only $89 \%$ of the direct radiation of a plane reference plot whereas the most thermophilous plot (ZM4) received 102 $\%$. This difference is reflected in species composition particularly with a high abundance of beech and hornbeam in the regeneration of ZM1 as well as the occurrence of Fagetalia species such as Carex pilosa, Drymochloa drymeja or Lamium galeobdolon as species mediating between mesic and thermophilous stands (see Table 3 and Supporting Information III; Coldea 1991, Chifu \& Irimia 2014, Coldea et al. 2015a, b).

\section{Conclusions}

The clear climate effect on species composition across and within the surveyed regions demonstrates the usefulness of regular vegetation monitoring to detect early climate change effects on forest ecosystems. Understorey and canopy tree species composition are strongly correlated indicating that a community-based characterization of forest stands provides information on tree species suitability of a specific site for production forests. Despite a long-term human impact on forest vegetation, tree species and understorey composition are both determined by macro- and mesoclimatic factors. A regular monitoring of this relationship between vegetation layers may help to indicate community change in the course of climate warming starting from the understorey with increasing abundance of thermophilous tree and shrub species. A closed canopy as an effect of increased productivity or changes in forest management (e.g. the transformation from coppice to high forest management) have buffered climate change effects on the understorey in many regions of Central Europe so far (De Frenne et al. 2013, Schmidt \& Heinrichs 2015). At marginal sites close to the distribution limit of forest communities as in the study region, species composition may show a faster response than in regions with more favorable climate and may give indications for future forest development there.

Outputs of species distribution models such as the climatic marginality index reliably predict the occurrence of tree species as demonstrated for $F$. sylvatica. For modelling the distribution edges of $Q$. petraea (s.str.) in Romania, existing phytosociological relevés that often differentiated $Q$. petraea into microspecies could be used as a reliable database to adjust indices in these marginal sites.

We conclude that climate driven forest vegetation composition in western Romania is a suitable analogon and can give indications on future forest development in Western Central 
Europe according to expected long-term future climate trends.

\section{Ackowledgements}

We would like to thank our colleagues Wolfgang Hetsch, Franz Kroiher, Albert Reif, Alois Simon, and undergraduate and phd-students of the Georg-August-University for their committed and competent assistance in field data collection in midsummer 2014. Tobias Mette provided background information to climate analogy.

\section{References}

Agee J.K., 1998. Fire and pine ecosystems. In: Richardson D.M. (ed.), Ecology and biogeography. Cambridge University Press, Cambridge, pp. 193-218.

Arbeitskreis Standortskartierung, 2016. Forstliche Standortsaufnahme: Begriffe, Definitionen, Einteilungen, Kennzeichnungen [Forest habitat mapping: terms, definitions, classifications, identifications, explanations]. Erläuterungen. 7th edition, IHW, Eching, 400 p.

Bolte A., Czajkowski T., Kompa T., 2007. The north-eastern distribution range of European beech - a review. Forestry 80: 413-429. DOI: 10.1093/forestry/cpm028

Borhidi A., 1995. Social behaviour types, the naturalness and relative ecological indicator values of the higher plants in the Hungarian Flora. Acta Botanica Hungarica 39 (1-2): 97-181.

Castro J., Zamora R., Hódar J.A., Gómez J.M., 2005. Ecology of seed germination of Pinus sylvestris L. at its southern, Mediterranean distribution range. Investigación Agraria. Sistemas y Recursos Forestales14: 143-152.

Chifu T., Irimia I., 2014. Diversitatea fitosociologica a vegetatiei Romaniei. III Vegetatia padurilor si tufisurilor [The phytosociological diversity of the Romania's vegetation. III Vegetation of forests and shrubs]. Institutul European, Iasi. $551 \mathrm{p}$.

Chytrý M., 1997. Thermophilous oak forests in the Czech Republic: Syntaxonomical revision of the Quercetalia pubescenti-petraeae. Folia Geobototanica et Phytotaxonomica 32: 221-258. DOI: 10.1007/BF02804006

Ciocârlan V., 2009. Flora ilustrată a României. Pteridophyta et Spermatophyta. Editura Ceres, București, 1138 p.

Coldea G., 1991. Prodrome des associations végétales des Carpates du sud-est (Carpates Roumaines) [Prodromus of vegetation associations of the south-east Carpathians (Romanian Carpathians)]. Doc. Phytosoc. N.S. 13: 317-539.
Coldea G., Pop A., 1996. Phytocoenologische Untersuchungen über die meso-thermophilen Eichenwälder Siebenbürgens [Phytocoenological investigation of the meso-thermophilous oak forests of Transylvania]. Stapfia 45: 55-64.

Coldea G., Ursu T., Filipaş L., Hurdu B.I., Stoica I.-A., 2015a. Phytosociological research in forests of Poiana Ruscăi Mountains. Contribuţii Botanice 2015: 123-135.

Coldea G., Indreica A., Oprea A., 2015b. Les associations vegetales de Roumanie. Tome 3. Les associations forestieres et arbustives [Vegetation associations of Romania. Volume 3. Forest and shrub associations]. Presa Universitara Clujeana. $281 \mathrm{p}$.

Czúcz B., Gálhidy L., Mátyás C., 2011. Present and forecasted xeric climatic limits of beech and sessile oak distribution at low altitudes in Central Europe. Annals of Forest Science 68: 99-108.

DOI: $10.1007 / \mathrm{s} 13595-011-0011-4$

De Frenne P., Rodríguez-Sánchez F., Coomes D.A., Baeten L., Verstraeten G., Vellend M., Bernhardt-Römermann M., Brown C.D., Brunet J., Cornelis J., Decocq G.M., Dierschke H., Eriksson O., Gilliam F.S., Hédl R., Heinken T., Hermy M., Hommel P., Jenkins M.A., Kelly D.L., Kirby K.J., Mitchell F.J.G., Naaf T., Newman M., Peterken G., Petř́k P., Schultz J., Sonnier G., Van Calster H., Waller D.M., Walther G.-R., Whitea P.S., Woods K.D., Wulf M., Graae B.J., Verheyen K., 2013. Microclimate moderates plant responses to macroclimate warming. PNAS 110: 18561-18565. DOI: 10.1073/pnas. 1311190110

Di Pietro R., Viscosi V., Peruzzi L., Fortini P., 2012. A review of the application of the name Quercus dalechampii. TAXON 61: 1311-1316.

Dierschke H., 1994. Pflanzensoziologie [Plant Sociology]. Ulmer, Stuttgart, 683 p.

Dolos K., Mette T., Wellstein C., 2016. Silvicultural climatic turning point for European beech and sessile oak in Western Europe derived from national forest inventories. Forest Ecology and Management 373: 128-137. DOI: 10.1016/j.foreco.2016.04.018

Doniță N., Ivan D., Coldea G., Sanda V., Popescu A., Chifu T., Paucă-Comănescu M., Mititelu D., Boșcaiu N., 1992. Vegetaţia României [Vegetation of Romania]. Ed. Tehnică Agricolă. București. 407p.

Ellenberg H., 1963. Vegetation Mitteleuropas mit den Alpen [Vegetation of Central Europe with the Alps]. 1st edition, Ulmer, Stuttgart.

Ellenberg H., Leuschner C., 2010. Vegetation Mitteleuropas mit den Alpen in ökologischer, dynamischer und historischer Sicht [Vegetation of Central Europe with the Alps in ecological, dynamic and historic view]. 6th edition, Ulmer, Stuttgart, $1357 \mathrm{p}$.

Enescu C.M., Dănescu A., 2013. Black Locust (Robinia pseudoacacia L.) - An invasive neophyte in the conventional land reclamation flora in Romania). Bulletin of the Transilvania University of Braşov, Series II 6(55): No. 2.

Falk W., Mellert K.H., 2011. Species distribution models 
as a tool for forest management planning under climate change: risk evaluation of Abies alba in Bavaria. Journal of Vegetation Science 22(4): 621-634. DOI: 10.1111/j.1654-1103.2011.01294.x

Fang J., Lechowicz M.J., 2006. Climatic limits for the present distribution of beech (Fagus L.) species in the world. Journal of Biogeography 33: 1804-1819. DOI: 10.1111/j.1365-2699.2006.01533.x

Fischer H.S., Gilgen H., 2002. DACHRad - Berechnung der direkten Sonneneinstrahlung in Deutschland, Österreich und der Schweiz [DACHRad - Calculation of direct radiation in Germany, Austria and Switzerland]. Bulletin of the Geobotanical Institute ETH: 68: 83-94.

Gärtner S., Reif A., Xystrakis F., Sayer U., Bendagha N., Matzarakis A., 2008. The drought tolerance limit of $\mathrm{Fa}$ gus sylvatica forest on limestone in southwestern Germany. Journal of Vegetation Science 19: 757-768. DOI: 10.3170/2008-8-18442

Hampe A., Petit R.J., 2005. Conserving biodiversity under climate change: the rear edge matters. Ecology Letters 8: 461-467. DOI: 10.1111/j.1461-0248.2005.00739.x

Hampe A., Jump A.S., 2011. Climate relicts: past, present, future. Annu. Rev. Ecol. Evol. Syst. 42: 313-333. DOI: 10.1146/annurev-ecolsys-102710-145015

Hancock M., Egan S., Summers R., Cowie N., Amphlett A., Rao S., Hamilton A., 2005. The effect of experimental prescribed fire on the establishment of Scots pine Pinus sylvestris seedlings on heather Calluna vulgaris moorland. Forest Ecology and Management 212: 199213. DOI: $10.1016 /$ j.foreco.2005.03.039

Herrero A., Rigling A., Zamora R., 2013. Varying climate sensitivity at the dry distribution edge of Pinus sylvestris and P. nigra. Forest Ecol Manage 308: 50-61. DOI: 10.1016/j.foreco.2013.07.034

Hijmans R.J., Cameron S.E., Parra J.L., Jones P.G., Jarvis A., 2005. Very high resolution interpolated climate surfaces for global land areas. International Journal of Climatology 25: 1965-1978. DOI: 10.1002/joc.1276

Hobi, M.L., Commarmot, B. \& Bugmann, H., 2015. Pattern and process in the largest primeval beech forest of Europe (Ukrainian Carpathians). Journal of Vegetation Science, 26 (2), 323-336. DOI: 10.1111/jvs.12234

Horvat I., Glavač V., Ellenberg H., 1974. Vegetation Südosteuropas [Vegetation of South-east Europe]. Fischer, Jena, 768 p.

Indreica A., 2011. On the occurence in Romania of Potentillo albae-Quercetum petraeae Libbert 1933 Association. Not. Bot. Hort. Agrobot. Cluj 39(1): 297-306.

IPCC, 2013. Climate change 2013: the physical science basis. Cambridge University Press, Cambridge, 1535 p.

Kottek M., Grieser J., Beck C., Rudolf B., Rubel F., 2006. World Map of the Köppen-Geiger climate classification updated. Meteorologische Zeitschrift 15: 259-263. DOI: $10.1127 / 0941-2948 / 2006 / 0130$

Lenoir J., Graae B.J., Aarrestad P.A., Alsos I.G., Armbruster W.S., Ausrheim G., Bergendorff C., Birks H.J.B., Bråthen K.A., Brunet J., Bruun H.H., Dahlberg C.J., Decocq G., Diekmann M., Dynesius M., Ejnæs
R., Gryntes J.-A., Hylander K., Klanderud K., Luoto M., Milbau A., Moora M., Nygaard B., Odland A., Ravolainen V.T., Reinhardt S., Sandvik S.M., Schei F.H., Speed, J.D.M., Tveraabak L.U., Vandvik V., Velle L.G., Virtanen R., Zobel M., Svenning J.-C., 2013. Local temperatures inferred from plant communities suggest strong spatial buffering of climate warming across Northern Europe. Global Change Biology 19:1470 1481. DOI: $10.1111 / \mathrm{gcb} .12129$

Leuschner C., 2015. Monospecific and mixed stands of Fagus and Nothofagus species in the temperate zones of the world. Berichte der Reinhold Tüxen-Gesellschaft 27: 49-63.

Maclean I.M.D., Hopkins J.J., Bennie J., Lawson C.R., Wilson R.J., 2015. Microclimates buffer the responses of plant communities to climate change. Global Ecology and Biogeography 24: 1340-1350.

DOI: $10.1111 /$ geb. 12359

Máliš F., Jarolimek I., Kliment J., Slezak M., 2013. Forest vegetation with Festuca drymeja in Slovakia - syntaxonomy and ecology. Phyton 53(2): 265-288.

Matacă S., 2005. Parcul Natural Portile de Fier. Flora, vegetatie si protectia naturii [Natural Park Iron Gates. Flora, Vegetation and Nature Conservation]. Ed. Universitaria Craiova, $550 \mathrm{p}$.

Mellert K.H., Deffner V., Küchenhoff H., Kölling C., 2015. Modeling sensitivity to climate change and estimating the uncertainty of its impact: A probabilistic concept for risk assessment in forestry. Ecological Modelling 316: 211-216. DOI: 10.1016/j.ecolmodel.2015.08.014

Mellert K.H., Ewald J., Hornstein D., Dorado-Li-án I., Jantsch M., Taeger S., Zang C., Menzel A., Kölling C., 2016. Climatic marginality: a new metric for the susceptibility of tree species to warming exemplified by Fagus sylvatica (L.) and Ellenberg's quotient. European Journal of Forest Research 135: 137-152. DOI: 10.1007/s10342-015-0924-9

Mette T., Dolos K., Meinardus C., Bräuning A., Reineking B., Blaschke M., Pretzsch H., Beierkuhnlein C., Gohlke A., Wellstein C., 2013. Climatic turning point for beech and oak under climate change in Central Europe. Ecosphere 4(12): Article 145. DOI: 10.1890/ES13-00115.1

Metz J., Annighöfer P., Schall P., Zimmermann J., Kahl T., Schulze E.-D., Ammer C., 2016. Site-adapted admixed tree species reduce drought susceptibility of mature European beech. Global Change Biology 22: 903-920. DOI: $10.1111 /$ gcb.13113

Murtagh F., Legendre P., 2014. Ward's hierarchical agglomerative clustering method: which algorithms implement Ward's criterion? Journal of Classification 31: 274-295. DOI: 10.1007/s00357-014-9161-z

Patricelli D., Sielezniew M., Ponikwicka-Tyszko D., Ratkiewicz M., Bonelli S., Barbero F., Witek M., Bu's M.M., Rutkowski R., Balletto E., 2013. Contrasting genetic structure of rear edge and continuous range populations of a parasitic butterfly infected by Wolbachia. BMC Evol Biol 13: 14. DOI: 10.1186/1471-2148-13-14 Pătroescu M., Chincea I., Rozylowicz L., Sorescu C. 
(eds.), 2007. Pădurile cu pin negru de Banat (Pinus nigra ssp. banatica) sit Natura 2000 [Forests with Banat black pine Natura 2000 Site]. Timisoara, Editura Brumar, 353 p. Web: http://de.scribd.com/doc/25301393/ Padurile-de-pin-negrude-Banat-Pinus-nigra-banatica-sit-Natura-2000. Accessed: 02.06.2016.

Pop I., Ardelean M., Codoreanu V., Crisan A., Cristea V., Csuros M., Csuros S., Ghisa E., Hodisan I., Ratiu E., Szasz E., 1978. Flora si vegetatia Muntilor Zarand [The flora and vegetation of Zarand Mountains]. Contrib. Bot. Cluj-Napoca, 1-215.

Rigling A, Bigler C, Eilmann B, Feldmeyer-Christe B, Gimmi U, Ginzler C, Graf U, Mayer P, Vacciano G, Weber, P, Wohlgemuth T, Zweifel R, Dobbertin M., 2013. Driving factors of a vegetation shift from Scots pine to pubescent oak in dry Alpine forests. Global Change Biology 19: 229-240. DOI: 10.1111/gcb.12038

Roleček J., 2005. Vegetation types of dry-mesic oak forests in Slovakia. Preslia 77: 241-261.

Rose L., Leuschner C., Köckemann B., Buschmann H., 2009. Are marginal beech (Fagus sylvatica L.) provenances a source for drought tolerant ecotypes? European Journal of Forest Research 128: 335-343. DOI: 10.1007/s10342-009-0268-4

Rouget M., Richardson D.M., Lavorel S., Vayreda J., Gracia C., Milton S.J., 2001. Determinants of distribution of six Pinus species in Catalonia, Spain. Journal of Vegetation Science 12: 491-502. DOI: 10.2307/3237001

Scharnweber T., Manthey M., Criegee C., Bauwe A., Schröder C., Wilmking M., 2011. Drought matters - declining precipitation influences growth of Fagus sylvatica L. and Quercus robur L. in north-eastern Germany. Forest Ecology and Management 262: 947-961. DOI: 10.1016/j.foreco.2011.05.026

Schmidt W., Heinrichs S., 2015. Umwelt- und Nutzungswandel im Kalkbuchenwald (Hordelymo-Fagetum lathyretosum) - Ein Vergleich alter und neuer Vegetationsaufnahmen aus dem Göttinger Wald [Environmental and land use change in beech forests on limestone (Hordelymo-Fagetum lathyretosum) - A comparison of old and recent vegetation surveys from the Göttinger Wald]. Hercynia N. F. 48: 21-50.

Schulze E.-D., Aas G., Grimm G.W., Gossner M.M., Walentowski H., Ammer C., Kühn I., Bouriaud O., von Gadow K., 2016. A review on plant-diversity and forest management of European beech forests. European Journal of Forest Research 135: 51-67. DOI: 10.1007/ s10342-015-0922-y

Tegel W., Seim A., Hakelberg D., Hoffmann S., Panev M., Westphal T., Büntgen U., 2014. A recent growth increase of European beech (Fagus sylvatica L.) at its Mediterranean distribution limit contradicts drought stress. European Journal of Forest Research 133: 61-71. DOI: $10.1007 / \mathrm{s} 10342-013-0737-7$

van der Maarel E., Franklin J. (eds.), 2013. Vegetation Ecology, 2nd Edition. Wiley-Blackwell, Oxford, 572 p.

Walentowski H., Bergmeier E. 2009. Geobotanical assessment of forest habitat types of the Habitats Directive in northwestern Turkey. Tuexenia 29: 297-303.

Walentowski H., Bergmeier, E., Evers, J., Hetsch, W., Indreica, A., Kroiher, F., Reif, A., Simon, A., Teodosiu, M., 2015. Vegetation und Standorte in Waldlandschaften Rumäniens [Plants and habitats of wooded landscapes in Romania]. Kessel-Verlag, Remagen-Oberwinter, 111 p.

Walter H., Breckle S.W., 1985. The law of relative constancy of habitat - ecotypes and ecolines. In: Walter H., Breckle S.W. (eds.), Ecological Systems of the Geobiosphere. Springer, Berlin, Heidelberg, pp. 194-202. DOI: 10.1007/978-3-662-02437-9_9

Zimmermann J., Hauck M., Dulamsuren C., Leuschner C., 2015. Climate warming-related growth decline affects Fagus sylvatica, but not other broad-leaved tree species in Central European mixed forests. Ecosystems 18: 560-572. DOI: $10.1007 / \mathrm{s} 10021-015-9849-\mathrm{x}$

\section{Supporting Information}

The online version of the article includes Supporting Information:

\section{Supp. Info. I. Map of the study regions}

Supp. Info. II. Linear regression functions for relating altitude and climate variables in the five different regions

Supp. Info. III. Complete vegetation surveys of the 18 plots 